\title{
Penghambatan Enzim Pemecah Protein (Papain) Oleh Ekstrak Rokok, Minuman Beralkohol Dan Kopi Secara In Vitro
}

\author{
La Ode Sumarlin, Siti Nurbayti, Syifa Fauziah \\ Program Studi Kimia Fakultas Sains dan Teknologi UIN Syarif Hidayatullah \\ Jakarta, Jalan Ir. H. Juanda No 95 Ciputat 15412 Indonesia \\ Email: sumarlin@uinjkt.ac.id
}

\begin{abstract}
Abstrak
Telah dilakukan penelitian tentang pengaruh ekstrak rokok, kopi dan minuman beralkohol terhadap aktivitas enzim papain. Tujuan penelitian ini untuk mengetahui pengaruh ekstrak rokok, kopi dan minuman beralkohol terhadap aktivitas enzim pencernaan terutama enzim protease dimana papain digunakan sebagai model. Enzim papain menghidrolisis substrat dihambat dengan mencegah interaksi antara gugus $-\mathrm{SH}$ dari Sis 25 dengan atom $\mathrm{N}$ imidazol dari His 159 dari papain untuk membuat sisi aktif. Hasil penelitian menunjukkan bahwa ekstrak rokok, ekstrak kopi dan minuman beralkohol masing-masing menunjukkan penghambatan terhadap aktivitas enzim papain sebesar $27,3 \%, 35 \%$, dan $22,3 \%$.
\end{abstract}

Kata Kunci: Rokok, kopi, alkohol, inhibitor, papain

\begin{abstract}
Has done research on the influence of Cigaretes extracts, coffee and alcoholic beverages on the activity of the enzyme papain. The purpose of this study to determine the effect of extracts of cigarettes, coffee and alcoholic beverages on the activity of digestive enzymes, especially protease enzyme papain which is used as a model. Papain enzyme hydrolyzes the substrate is inhibited by preventing the interaction between-SH groups of Cys 25 with imidazole $\mathrm{N}$ atom of His 159 of papain to make the active side. The results showed that the extract of cigarettes, coffee and alcoholic extracts each showed inhibition against papain enzyme activity of $27.3 \%$, 35\%, and $22.3 \%$.
\end{abstract}

Keywor ds: Cigarettes, coffee, a lcohol, inhibitor, papain

\section{PENDAHULUAN}

Rokok, kopi dan minuman beralkohol adalah bahan yang banyak dikonsumsi oleh manusia baik secara nasional maupun di dunia Internasional. Ditinjau dari segi kebutuhan tubuh baik untuk pertumbuhan, perbaikan dan menjaga fungsi sel dan organ, ketiga bahan tersebut tidak dibutuhkan.

Banyak penelitian klinis membuktikan berbagai kerusakan organ tubuh akibat konsumsi ketiga bahan tersebut seperti rokok dapat menyebabkan gangguan saluran pernapasan (seperti asma, kanker paru-paru dan kanker larings), gangguan saluran pencernaan, penurunan sensitivitas trombosit, dan sebagainya (Doll dan Hill, 1964). Kopi dapat menstimulasi pernafasan dan jantung, serta memberikan efek samping berupa rasa gelisah, tidak dapat tidur (insomnia), dan denyut jantung tak beraturan (Ranheim dan Halvorsen, 2005). Minuman beralkohol dapat menyebabkan penyakit pada hati, seperti siros is atau kanker hati. Selain itu juga dapat menimbulkan penyakit jantung, gagal jantung dan tekanan darah tinggi atau stroke (Fachmi, 2006).

Penelitian ini ingin melihat efek ketiga bahan tersebut melalui mekanisme enzimatik terhadap enzim saluran pencernaan terutama pada enzim protease. Sebagai model digunakan enzim papain karena enzim papain 
termasuk sistein protease golongan endopeptidase dimana papain dapat memecah protein pada tempat-tempat tertentu dalam molekul protein. Di samping itu, enzim papain (EC 3.4.22.2) memiliki sifat dan mekanisme katalitik yang mirip dengan enzim cathepsin (EC 3.4.22) yaitu enzim siste in protease yang diisolasi dari jaringan hati mammalia dan termasuk juga golongan endopeptidase (Otto dan Schirme ister, 1997).

Papain merupakan salah satu jenis enzim hidrolase yang bersifat proteolitik.. Papain oleh Komisi Enzim Internasional diklasifikasikan ke dalam EC 3.4.22.2 dimana

(3) menunjukkan kelas Hidrolase, menunjukkan sub-kelas amidase, dan (22) menunjukkan sub-sub kelas endopeptidase (Suhartono, 1991).

Beveridge (1996) menjelaskan bahwa papain memiliki sisi aktif yang terdiri atas asam amino sistein dan histidin. Diantara kedua asam amino tersebut, asam amino yang sangat bersifat reaktif adalah sistein, dimana di dalam sistein tersebut terdapat sebuah gugus tiol (-SH). Oleh karena itu, papain digolongkan ke dalam protease tiol (Suhartono, 1991). Menurut Poedjiadi (2006), papain juga tergolong ke dalam endopeptidase, dimana papain dapat memecah prote in pada tempattempat tertentu dalam molekul prote in dan biasanya tidak mempengaruhi gugus yang terletak di ujung molekul.

Diharapkan penelitian ini akan memberikan informasi mengenai kemampuan penghambatan dari ekstrak rokok, kopi dan minuman beralkohol terhadap enzim protease dalam tubuh. Terhambatnya protease oleh inhibitor akan menyebabkan terganggunya organisme dalam menguraikan protein, sebaliknya percepatan aktivitas yang tidak terkontrol juga dapat berakibat fatal bagi organisme. Oleh karena itu, sangat penting untuk mengetahui sejauh mana ekstrak dari ketiga komponen tersebut dapat mempengaruhi aktivitas enzim papain sebagai analog enzim protease dalam tubuh. Dihrapkan penelitian ini juga bisa menjadi informasi awal untuk penelitian secara in vivo

\section{METODE PENELITIAN}

\section{Alat dan Bahan}

Bahan-bahan yang digunakan dalam penelitian ini meliputi enzim papain (EC 3.4.22.2 Merck from Carica papaya, water soluble $3000 \mathrm{USP}-\mathrm{U} / \mathrm{mg}$ ), $\mathrm{NaOH} 5 \mathrm{~N}, \mathrm{HCl} 5 \mathrm{~N}$, $\mathrm{Na}_{2} \mathrm{HPO}_{4} \cdot 2 \mathrm{H}_{2} \mathrm{O}, \mathrm{KH}_{2} \mathrm{PO}_{4} \cdot 2 \mathrm{H}_{2} \mathrm{O}$, kasein, bufer fosfat pH 6,5, Coomassie Briliant Blue G-250, etanol $95 \%$, asam fosfat $85 \%$, Bovine Serum Albumin (BSA) dan akuades. Sebagai penghambat atau inhibitor digunakan ekstrak rokok, kopi dan minuman beralkohol. Sampel rokok yang digunakan yaitu rokok Kretek. Kopi yang dijadikan sampel diambil dari kopi Lampung dengan berbagai konsentrasi, serta minuman beralkohol dengan kadar $43 \%$.

Alat-alat yang digunakan antara lain neraca analitik, hotplate, waterbath incubator, $\mathrm{pH}$ meter, spektrofotometer UV-VIS dengan $\lambda$ 595 (Perkin Elmer), vorteks mixer, sentrifuge $10.000 \mathrm{~g}$ dan alat-alat gelas.

\section{Penentuan Kadar Protein}

Kadar protein enzim diukur dengan menggunakan pereaksi Bradford.

\section{Pembuatan Larutan Kasein}

Larutan kasein $20.000 \mathrm{ppm}$ dibuat dengan cara menimbang $2 \mathrm{~g}$ kasein dan melarutkannya ke dalam $100 \mathrm{~mL}$ akuades dan pH diatur 8,0 dengan $\mathrm{NaOH} 5 \mathrm{~N}$ dan $\mathrm{HCl} 5 \mathrm{~N}$. Campuran yang dihasilkan diinkubasi semalaman dengan pengadukan pada suhu $60^{\circ} \mathrm{C}$. Larutan kasein tersebut disaring dengan kertas saring. Filtrat kemudian disentrifugasi pada kecepatan $10.000 \mathrm{~g}$ selama 15 menit. Larutan ini digunakan sebagai larutan stok untuk pembuatan larutan kasein 300 ppm.

\section{Pembuatan Larutan Papain}

Larutan papain 10.000 ppm dibuat dengan cara menimbang $500 \mathrm{mg}$ serbuk papain dan melarutkannya ke dalam $50 \mathrm{mM}$ Natrium Fosfat dengan $\mathrm{pH}$ 6,5 sebagai larutan stok. Selanjutnya dibuat larutan papain 2.000 ppm. 


\section{Uji Penghambatan Aktivitas Papain}

Uji daya inhibisi ekstrak rokok, kopi dan minuman beralkohol terhadap enzim papain dilakukan pada kondisi optimumnya. Kondisi optimum pengujian mengacu pada hasil penelitian Shukor et al. (2006), yaitu pada waktu inkubasi 30 menit, suhu $40^{\circ} \mathrm{C}, \mathrm{pH} 6,5$, konsentrasi larutan papain $2.000 \mathrm{ppm}$, dan konsentrasi larutan substrat (kasein) 300 ppm.

Larutan papain 2.000 ppm sebanyak 0,5 $\mathrm{mL}$ ditambahkan $5 \mathrm{~mL}$ bufer fosfat $100 \mathrm{mM}$ dengan $\mathrm{pH} 6,5$ dan sampel dengan range 0,25 , 0,5, 2,5 dan 4,5 $\mathrm{mL}$ dengan volume akhir dibuat sampai dengan $10 \mathrm{~mL}$ menggunakan akuades dan campuran diinkubasi selama 20 menit pada suhu kamar. Setelah masa inkubasi, ditambahkan larutan kasein 300 ppm sebanyak $5 \mathrm{~mL}$. Sebagai kontrol, larutan sampel digantikan dengan akuades.

Sebanyak $2 \mathrm{~mL}$ larutan uji dimasukkan ke dalam tabung reaksi dan ditambahkan $5 \mathrm{~mL}$ pereaksi Bradford dye dan diinkubasi selama 5 menit. Larutan diukur absorbansinya pada 595 nm untuk waktu nol (tanpa inkubasi). Larutan sisanya diinkubasi pada $40^{\circ} \mathrm{C}$ selama 30 menit. Setelah masa inkubasi, $2 \mathrm{~mL}$ dari larutan tersebut diambil lagi dan diperlakukan dengan cara yang sama dengan larutan pada waktu nol.

\section{Pembuatan Larutan Standar BSA}

BSA ditimbang sebanyak $10 \mathrm{mg}$ lalu ditambahkan $50 \mathrm{~mL}$ akuades dan diaduk. Larutan BSA 200 ppm ini digunakan untuk pembuatan kurva standar BSA untuk menentukan aktivitas papain.

Larutan BSA 200 ppm diambil sebanyak 10 ppm, 20 ppm, 30 ppm, 40 ppm, 50 ppm, 60 ppm, 70 ppm, dan 80 ppm dan ditambahkan pereaksi Bradford $2 \mathrm{~mL}$. Campuran diinkubasi selama 5 menit pada suhu $30^{\circ} \mathrm{C}$. Blanko yang digunakan adalah akuades yang ditambahkan dengan pereaksi Bradford sebanyak $2 \mathrm{~mL}$. Pengukuran absorbansi dilakukan secara spektroskopi pada panjang gelombang $595 \mathrm{~nm}$ dan dibuat kurva antara konsentrasi larutan BSA terhadap absorbansi.

\section{Pembuatan Sampel Inhibitor}

Sampel ekstrak rokok dibuat dengan cara melarutkan 4 batang rokok $(7,8 \mathrm{~g})$ dengan pelarut akuades dan direndam selama satu hari (maserasi), dengan variansi volume akuades 50 $\mathrm{mL}, 100 \mathrm{~mL}$, dan $250 \mathrm{~mL}$. Sampel ekstrak kopi dibuat dengan cara melarutkan $10 \mathrm{~g}$ kopi dengan akuades dengan variansi volume 50 $\mathrm{mL}, 100 \mathrm{~mL}$, dan $250 \mathrm{~mL}$. Sampel minuman alkohol dengan kadar alkohol $43 \%$ yang siap digunakan.

\section{Aktivitas Relatif $(\%)=$ AE/AK x $100 \%$ \\ $\mathrm{AE}=$ aktivitas papain dengan adanya inhibitor \\ $\mathrm{AK}=$ aktivitas papain tanpa inhibitor}

Pada penelitian ini, 1 unit aktivitas papain didefinisikan sebagai jumlah kasein (dalam $\mathrm{mg}$ ) yang dihidrolis is per menit oleh 1 mg protease pada kondisi percobaan tertentu (Shukor et al., 2006).

\section{HASIL DAN PEMBAHASAN}

\section{Enzim papain dan mekanisme inhibisi}

Mekanisme kerja papain melibatkan triad katalitik yang terbentuk antara Cys25, His 159, dan Asn 175. Gugus amida dari Asn 175 akan menarik proton dari inti imidazol His 159 sehingga kebasaannya meningkat. Inti imidazol dari His 159 akan menarik $\mathrm{H}^{+}$dari-SH pada Cys25 sehingga kenuklofilikan gugus $\mathrm{SH}$ bertambah. Sementara itu nitrogen amida dari Cys25 membentuk ikatan hidrogen dengan atom $\mathrm{O}$ gugus karbonil pada substrat. Ikatan hidrogen kedua terbentuk antara gugus $-\mathrm{NH}_{2}$ dari Gln 19 dengan $\mathrm{O}$ gugus karbonil pada substrat. Keadaan ini akan mempermudah penyerangan ion sulfida $\left(\mathrm{S}^{2-}\right)$ terhadap gugus $\mathrm{C}=\mathrm{O}$ dari substrat yang diikuti oleh pecahnya 
ikatan peptida dari substrat membentuk suatu

amina (Gambar 1) (Fersht, 1985).

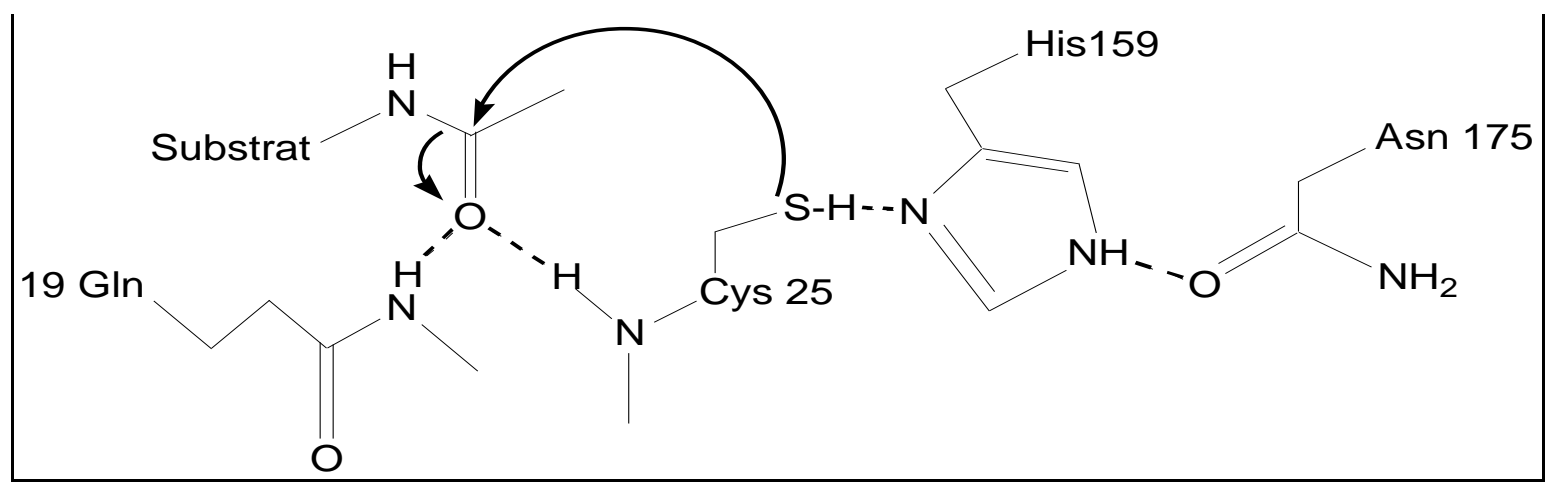

Gambar 1. Skema mekanisme kerja enzim papa in (Sumber: Tutik, 2003)

Aktivitas enzim papain ditandai dengan proses pemecahan substrat menjadi produk oleh asam amino His dan Sis pada sisi aktif enzim. Selama proses hidrolisis prote in, gugus-gugus amida akan terhidrolis is oleh papain secara bertahap (Gambar 2).

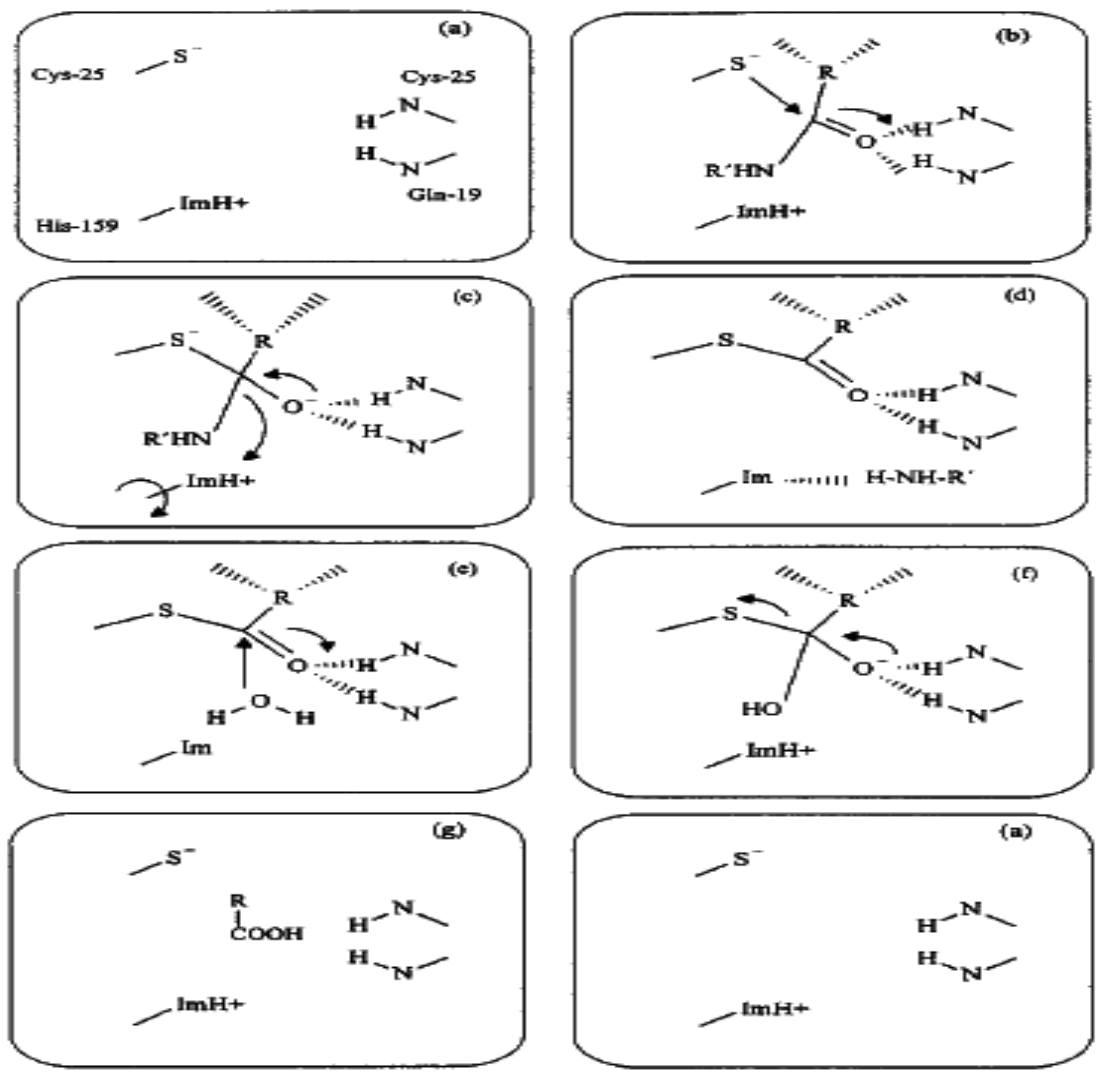

Gambar 2. Proses katalis hidrolisis gugus-gugus amida oleh papain (Sumber : Otto dan Schirmester, 1997). 
Pertama, asam amino Sis 25 yang bersifat sangat reaktif berikatan dengan substrat pada sisi aktif papain sehingga dihasilkan ikatan kovalen substrat dengan enzim yang berbentuk tetrahedral. Asam amino His159 terprotonasi sehingga berikatan dengan nitrogen yang terdapat di dalam substrat. Hasilnya gugus amida pada substrat akan terdifusi dan kedudukannya digantikan oleh molekul-molekul air yang akan menghidrolisis hasil intermediet. Molekul enzim akan kembali ke dalam bentuk dan fungsinya seperti semula (Sabariyyah, 2005).

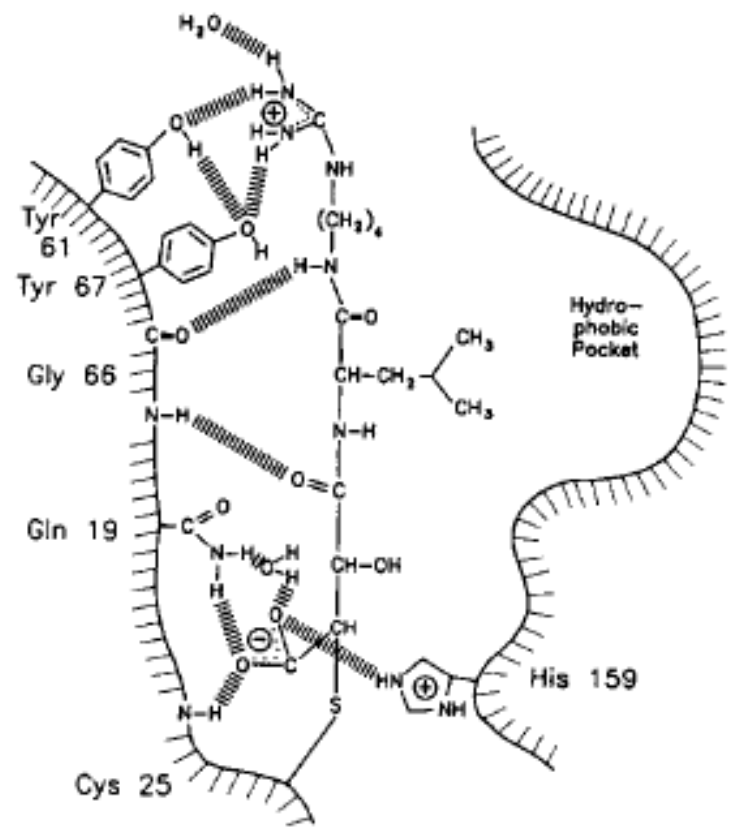

Gambar 3. Diagram skematik ko mpleks enzim-inhibitor E-64 dan papain (Su mber: Otto dan Schirme ister, 1997).

Sisi aktif dibentuk oleh residu asam amino Sis25 dan His159. Gambar 4 menunjukkan selektivitas Enzim papain.

Menurut Berger dan Schechter, (Gambar 4), papain memiliki tujuh subsites sisi aktif yang masing-masing dapat mengikat residu asam amino substrat. Papain sangat baik dalam melepaskan peptida pada residu Arg dan Lis (P1), tapi subsite $\mathrm{S} 1$ memiliki spesifitas yang lebih rendah dibandingkan subsite $\mathrm{S} 2$, yang memiliki sisi rantai hidrofobik seperti Phe. Situs S2 dari enzim bersifat hidrofobik, dibentuk oleh residu amino residu asam Trp69, Tir67, Phe207, Pro68, Ala160, Vall33, dan Val157.

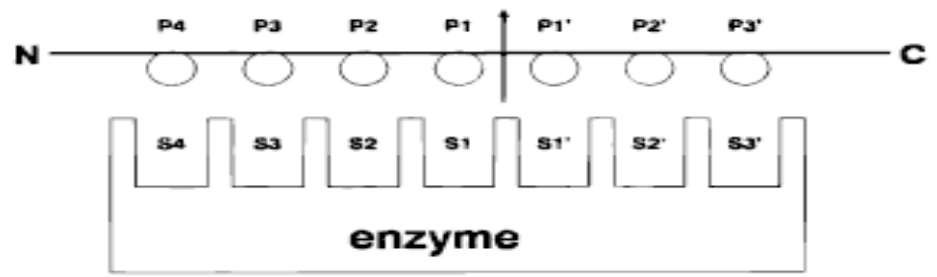

Gambar 4. Model dari spesifitas enzim protease (Su mber: Otto dan Schirme ister, 1997). 
Papain adalah terisolasi sebagai bentuk tidak aktif, terdapat residu sistein pada situs aktif diblokir oleh ikatan disulfida dengan Cys22 dan Cys63 yang memiliki kelompok thiol bebas. Proses sebaliknya berupa aktivasi dimungkinkan oleh pertukaran disulfida intramolekul dengan reagen thiol atau dengan agen reduksi (Otto dan Schirme ister, 1997).

\section{Daya Hambat Ekstrak Rokok te rhadap Aktivitas Enzim Papain}

Analisis daya hambat ekstrak rokok terhadap enzim papain, dilakukan pada berbagai variasi konsentrasi dari ekstrak yang didasarkan pada dosis letal nikotin yang merupakan senyawa komponen penyusun rokok. Menurut Susanna (2003) bahwa dosis letal nikotin pada manusia sekitar $60 \mathrm{mg}$. Satu batang rokok putih mengandung nikotin antara 15 - $20 \mathrm{mg}$ (Alaunir, 1992), sehingga 4 batang rokok ketika di ekstraksi sudah mengandung kadar nikotin dengan dosis letal.

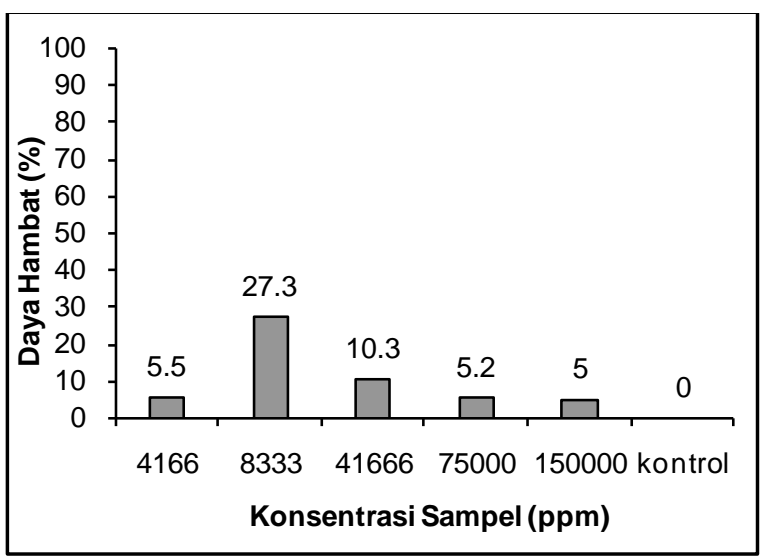

Gambar 5. Daya hambat ekstrak rokok terhadap aktivitas enzim papain

Pada Gambar 5 menunjukkan peningkatan daya hambat terjadi dari konsentrasi 8333 ppm dan penurunan terjadi pada konsentrasi $4166 \mathrm{ppm}$. Penurunan daya inhibisi ini diduga karena adanya senyawa pereduksi yaitu asam sianida yang terkandung dalam ekstrak rokok yang dapat mengaktifkan kembali aktivitas enzim papain (Muchtadi et al., 1992). Komponen yang terkandung dalam rokok diantaranya yaitu tar, nikotin, karbon monoksida, asam sianida dan fenol (Stedman, 1968).

Hasil analisis menunjukkan bahwa ekstrak rokok dapat menghambat aktivitas papain. Daya hambat tertinggi pada ekstrak rokok terjadi pada konsentrasi 8333 ppm dengan aktivitas relatif $72,7 \%$ dan daya hambatnya sebesar $27,3 \%$. Konsentrasi ini merupakan pengenceran dari rokok sebanyak 4 batang yang dilarutkan da lam $100 \mathrm{~mL}$ akuades (75000 ppm), yang diambil sebanyak $0,5 \mathrm{~mL}$ dengan volume zat setelah pengenceran sebesar $4,5 \mathrm{~mL}$.

Terjadinya hambatan pada rokok tersebut dapat diduga bahwa senyawa yang berperan sebagai inhibitor berhubungan dengan komponen yang terkandung di dalam rokok tersebut diantaranya yaitu gugus $-\mathrm{OH}$ fenolik. Fenol merupakan asam yang lebih kuat dari pada alkohol, pKa fenol sendiri adalah 10, hal ini dikarenakan anion yang dihasilkan dapat distabilkan oleh resonansi, dengan muatan negatifnya disebar (delokalisasi) oleh cincin aromatik (Fessenden dan Fessenden, 1986). Fenol dalam rokok merupakan salah satu bahan yang terkandung dalam tar, sedangkan sebatang rokok mengandung 10-30 mg tar (Aditama, 1997).

Atom $\mathrm{N}$ pada imidazol akan berikatan dengan fenol yang mempunyai keasaman tinggi sehingga terbentuk ikatan hidrogen intramolekular. Adanya ikatan hidrogen intramolekular sangat meningkatkan keasaman fenol, area inilah yang akan berinteraksi dengan inti imidazol dari His159 dan mencegah ionisasi gugus - $\mathrm{SH}$ dari asam amino Sis25 sehingga kenukleofilikannya menjadi rendah, keadaan ini membuat Sis25 sebagai gugus aktif enzim papain tidak dapat menyerang gugus $\mathrm{C}=\mathrm{O}$ dari substrat dan menghambat enzim papain untuk menghidrolis is substrat (Gambar 6). 


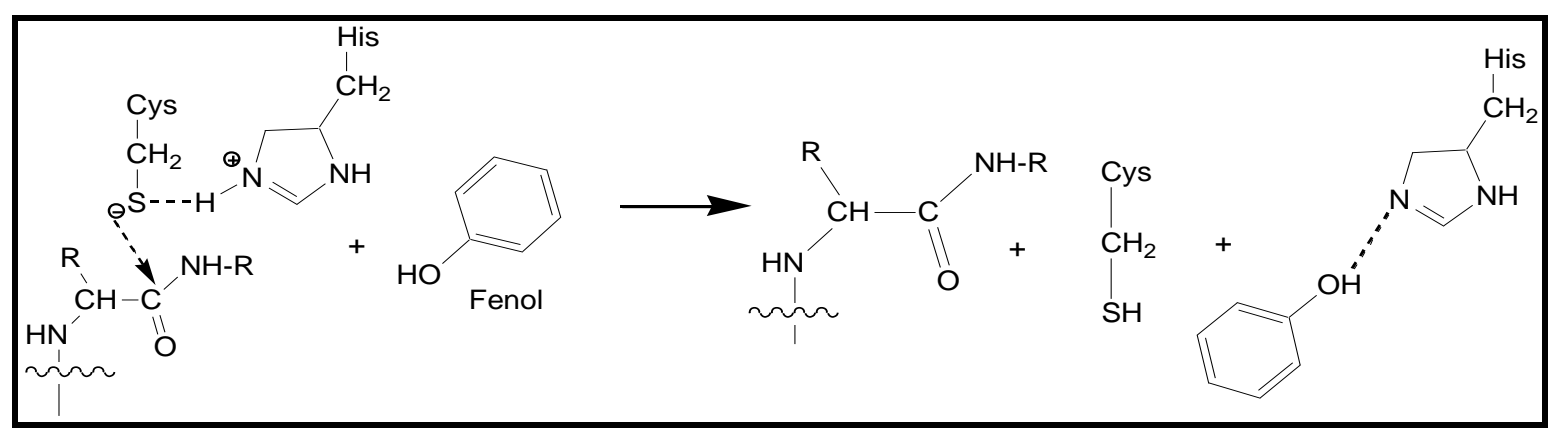

Gambar 6. Mekanisme penghambatan yang disarankan antara enzim papa in dengan inhibitor fenol (Sumber: Fressenden dan Fressenden, 1986; Budiati et al, 2004)

\section{Daya Hambat Ekstrak Kopi terhadap Enzim Papain}

Analisa terhadap ekstrak kopi juga membuktikan adanya penghambatan aktivitas papain. Analisis daya hambat ekstrak kopi terhadap enzim papain ini dilakukan pada berbagai variasi konsentrasi dari ekstrak yang didasarkan pada dosis letal kafein da lam tubuh. Dosis letal (mematikan) kafein dalam The Pharmacological Basis of Therapeutics 1975 disebutkan bahwa pada sampel kopi adalah sekitar 10 gram.

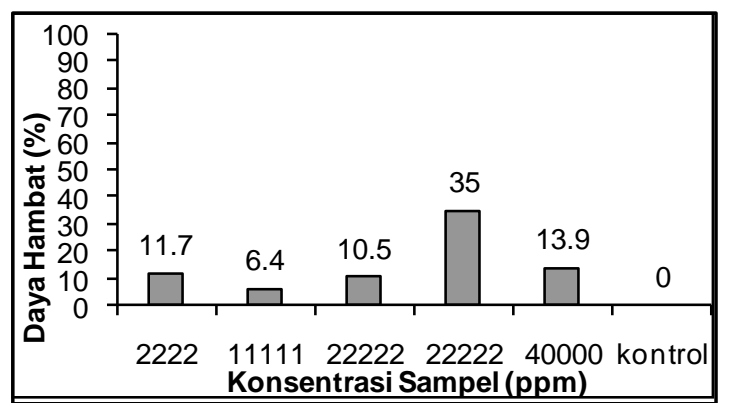

Gambar 7. Daya hambat ekstrak kopi terhadap aktivitas enzim papain

Daya hambat tertinggi pada ekstrak kopi terjadi pada konsentrasi 22222 ppm dengan aktivitas relatif $65 \%$ dan daya hambatnya sebesar $35 \%$. Konsentrasi ini merupakan pengenceran dari kopi sebanyak 10 g yang dilarutkan dalam $50 \mathrm{~mL}$ akuades (200.000 ppm), yang diambil sebanyak $2,5 \mathrm{~mL}$ dengan volume zat setelah pengenceran sebesar 4,5 mL.
Pada Gambar 7 memperlihatkan peningkatan dan penurunan daya hambat. Penurunan terjadi pada konsentrasi 40000 ppm. Peningkatan dan penurunan yang tidak signifikan ini diduga adanya karakteristik komponen senyawa yang berbeda dalam sampel yang ikut terekstrak. Menurut Kirk dan Othmer (1964) komponen terbanyak dalam kopi adalah kafein $(0,9-1,2 \%$ berat) dan asam klorogenat (5,5-8,0 \% berat).

Terjadinya hambatan pada kopi tersebut dapat diduga bahwa senyawa yang berperan sebagai inhibitor adalah asam klorogenat yang ada dalam kopi. Menurut Das et al., (1984). Asam klorogenat mempunyai gugus karboksilat $-\mathrm{COOH}$ dan gugus $-\mathrm{OH}$ intramolekul dan intermolekul (Gambar 8).

Dalam biji kopi, konsentrasi asam klorogenat sangat tinggi, dan kandungan asam klorogenat yang mudah larut dalam kopi kering dapat mencapai $12 \%$ berdasarkan bobot (Salisbury dan Ross, 1995). Asam klorogenat merupakan asam karboksilat yaitu senyawa organik yang mengandung gugus karboksil ($\mathrm{COOH})$. Gugus karboksil mengandung sebuah karbonil dan sebuah gugus hidroksil, antar-aksi dari kedua gugus ini mengakibatkan suatu kereaktivan yang unik untuk asam karboksilat Karena itu, gugus karboksil bersifat polar dan tak terintangi, sehingga reaksinya tidak dipengaruhi oleh sisa molekul. Sifat kimia yang paling menonjol dari asam karboksilat adalah keasamannya, asam karboksilat adalah asam lemah (pKa yang khas adalah sekitar 5), 
namun asam karboksilat lebih bersifat asam daripada alkohol atau fenol, terutama karena stabilisasi resonansi anion karboksilatnya, $\mathrm{R}$ $\mathrm{CO}_{2}^{-}$(Fessenden dan Fessenden, 1986). Sangatlah mungkin bahwa gugus $-\mathrm{COOH}$ diperlukan untuk membentuk ikatan hidrogen intramolekuler, sehingga menyebabkan terbentuknya konfigurasi molekul yang sesuai dengan konfigurasi pusat aktif dari papain (Budinti et al., 2004).

Gugus - SH berperan sebagai sisi aktif dalam enzim protease untuk menjalankan fungsinya. Gugus - SH hanya terdapat dalam satu asam amino saja, yaitu sistein, yang merupakan analog - $\mathrm{SH}$ dari serin, rumus sistein adalah $\mathrm{HSCH}_{2}-\mathrm{CHNH}_{2}-\mathrm{COOH}$ (Sadikin, 2002). Senyawa asam klorogenat memiliki gugus $-\mathrm{COOH}$ dan gugus $-\mathrm{OH}$, gugus ini merupakan gugus pemberi proton dan dapat berikatan hidrogen dengan atom $\mathrm{N}$ pada imidazol dari asam amino His 159 sehingga mencegah ionisasi gugus $-\mathrm{SH}$ dari asam amino Sis25 untuk membentuk sisi aktif sehingga substrat tidak dapat lagi mencapai sisi katalitik dan enzim tidak dapat lagi melakukan fungsinya untuk menghidrolisis kasein.

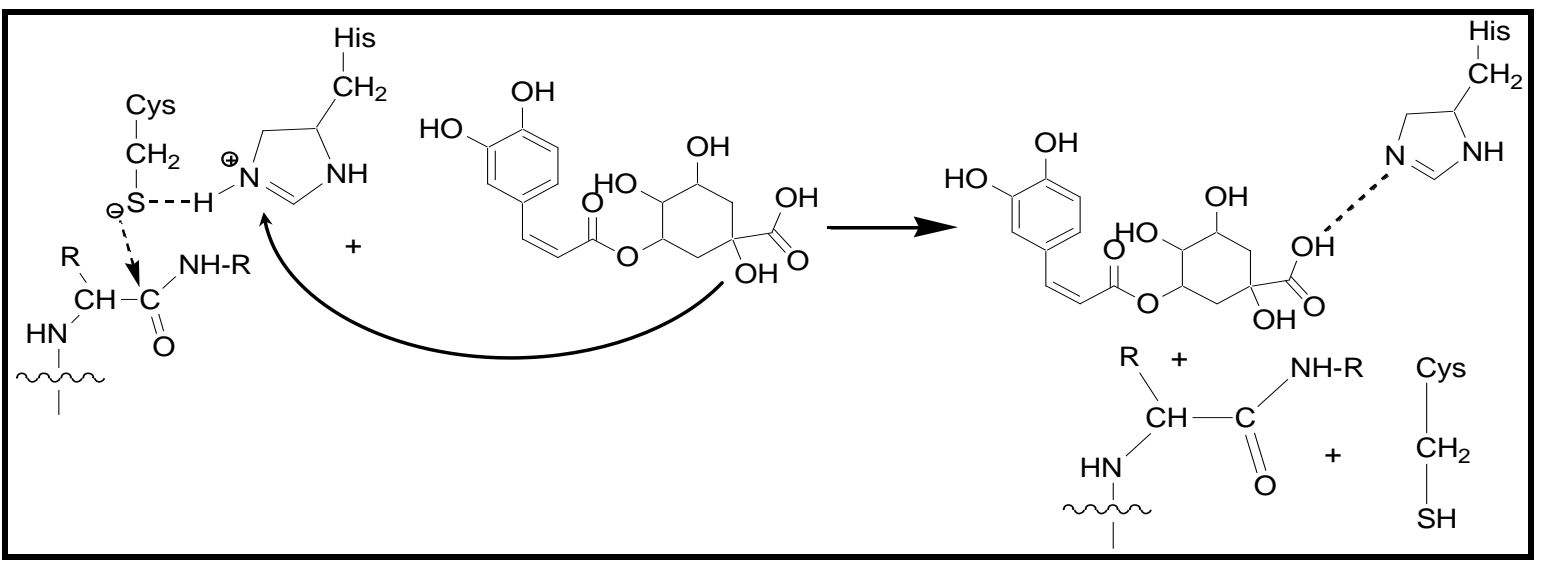

Gambar 8. Mekanisme penghambatan yang disarankan antara enzim papain dengan inhibitor asam klorogenat

Berdasarkan penelitian Budiati et al. (2004), metilasi terhadap gugus $-\mathrm{OH}$ fenolik dan gugus - $\mathrm{COOH}$ dapat mengurangi efek hambatan, karena gugus-gugus tersebut diperlukan untuk membentuk ikatan hidrogen sehingga ketika gugus tersebut dimetilasi akan meniadakan ikatan hidrogen tersebut.

\section{Daya Hambat Minuman Beralkohol terhadap Enzim Papain}

Hasil analis is aktivitas relatif minuman beralkohol terhadap enzim papain (Gambar 9), menunjukkan bahwa minuman beralkohol berpotensi menjadi penghambat terhadap penguraian prote in oleh enzim protease. Daya hambat tertinggi pada minuman beralkohol terjadi pada konsentrasi 38.222 ppm dengan aktivitas relatif $77,7 \%$ dan daya hambatnya sebesar $22,3 \%$.

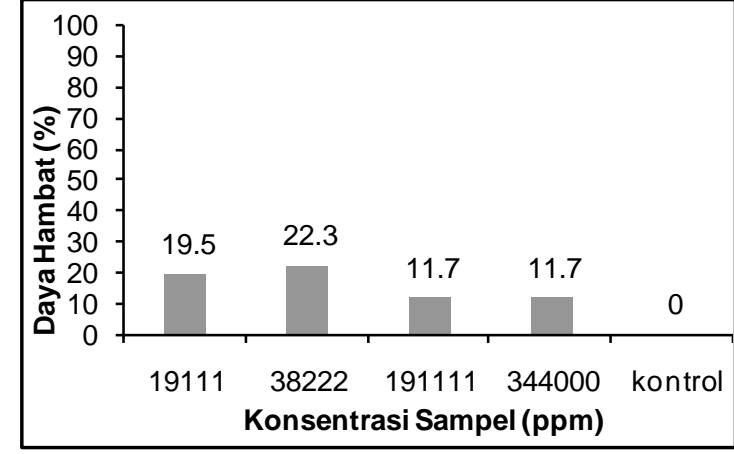

Gambar 9. Daya hambat minu man beralkohol terhadap aktivitas enzim papain

Proses penghambatan ini terjadi karena alkohol mengandung suatu oksigen dengan dua pasang elektron valensi menyendiri yang bersifat polar, sehingga alkohol dapat membentuk ikatan hidrogen antara molekul-molekulnya, dengan air 
maupun senyawa lain apa saja, yang mengandung $\mathrm{NH}$ atau $\mathrm{OH}$ (Fessenden dan Fessenden, 1986).

Menurut Lehninger (1982) bahwa gugus sulfihidril (-SH) dari residu Sis25 dan gugus imidazol dari residu His159 dapat dihambat oleh gugus hidroksil. Atom N imidazol dari asam amino His159 bereaksi dengan senyawa alkohol dan membentuk ikatan hidrogen antar molekul maka gugus SH tidak terionisasi dan kenukleofilikannya menjadi rendah, sehingga gugus aktif pada enzim papain yaitu gugus - $\mathrm{SH}$ dari residu Sis 25 yang terdapat disisi katalitik enzim tidak dapat melakukan fungsinya yaitu menghidrolis is kasein (Gambar 10).

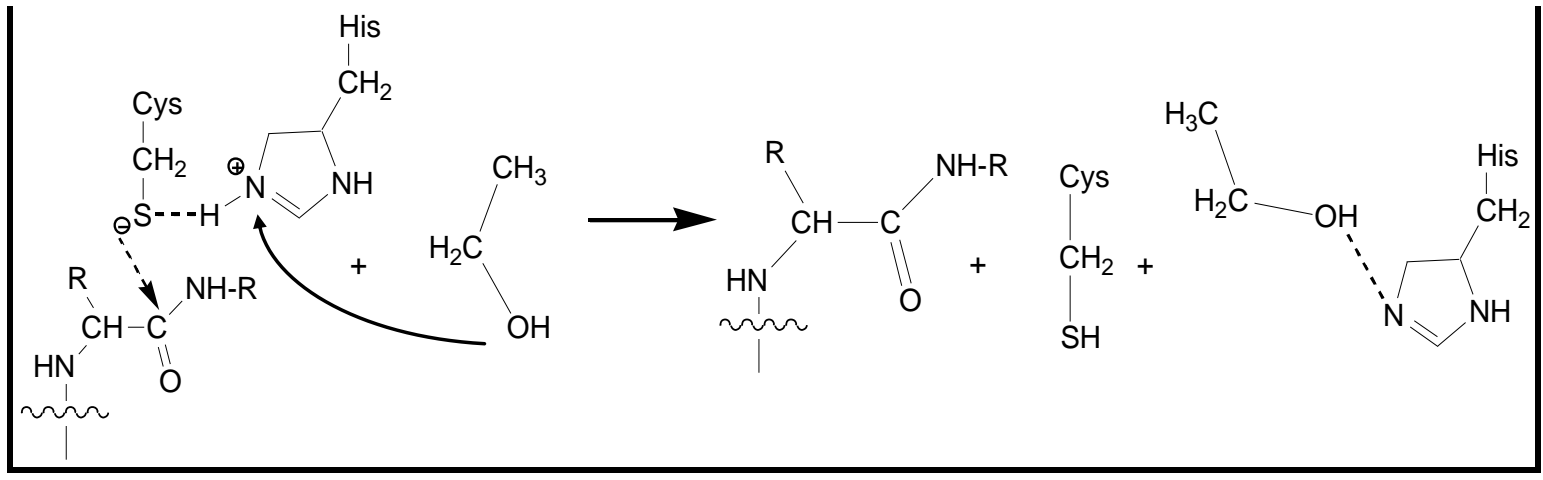

Gambar 10. Mekan isme penghambatan yang disarankan antara enzim papain dengan inhibitor etanol

\section{KESIMPULAN \& SARAN}

\section{Kesimpulan}

Berdasarkan hasil pene litian diperoleh kesimpulan sebagai berikut :

1. Sampel ekstrak rokok, kopi dan minuman beralkohol menunjukkan adanya penghambatan terhadap aktivitas enzim papain.

2. Daya hambat ekstrak rokok sebesar 27,3\%, ekstrak kopi 35\%, minuman beralkohol 22,3\%.

\section{Saran}

Perlu dilakukan analisis lebih lanjut untuk menentukan tipe kinetika inhibisi ekstrak rokok, kopi dan minuman beralkohol terhadap enzim papain. Perlu adanya kajian lebih lanjut dengan pendekatan molecular modelling (docking) secara in-silico.

\section{UCAPAN TERIMAKASIH}

Penulis mengucapkan terimakasih kepada Pusat Penelitian dan Pengabdian Masyarakat Fakultas Sains dan Teknologi yang telah mendanai kegiatan penelitian ini.

\section{DAFTAR PUSTAKA}

1. Aditama, TY. 1997. Rokok dan Kesehatan. Ed isi Ke tiga. UI Press. Jakarta

2. Alaunir N. 1992. Penentuan Kadar Nikotin dalam Berbagai Merk Rokok yang Beredar di Sumatera Barat. Padang: IKIP Padang. (Laporan Penelitian.).

3. Beveridge A J. 1996. A Theoritical Study of the Active Sites of Papain and S195C Rat Tripsin: Implication for the Low Reactivity of Mutant Serine Proteinases. Cambridge University Press: Journal of Protein Science. 
4. Budiati, T. Noor C., dan Soekeni S. 2004. Sintesis Metil Anakardat dan Uji Aktivitasnya sebagai Inhibitor Enzim Sulfhidril (The Syntheses and Sulfhydryl Enzyme Inhibition of Methyl Derivates of Anacardic Acid). JBP 6(2): 47-51.

5. Das, M., D.R. Bickers, and H. Mukhtar, 1984, Plant Fenols as in vitro Inhibitors of Glutathione S-Transferase, Biochem. Biophys. Res. Commun., 120 (2), 427-433.),

6. Doll, R. \& A.B.Hill. 1964. Mortality in relation to smoking: ten years' observations of British doctors. Brit. Med.J. 1: 1460-1467.

7. Fachmi, A.P. 2006. Penetapan kadar etanol dan metanol pada minuman beralkohol secara kromatografi gas. UI. FMIPA. Departemen Farmasi. Depok.

8. Fersht A, 1985. Enzyme: Structure and mechanism, $2^{\text {nd }}$ Edition, New York: $\mathrm{Wr}$ Freeman and Company.

9. Fressenden R. dan J. Fressenden. 1986. Kimia Organik. Jakarta: Erlangga.

10. Kirk R E, Othmer J B. 1953. Encyclopedia of chemical technology. Vol.5 hal 299-300. new york: the interscience encyclopedia lnc.

11. Lehninger AL. 1982. Dasar-dasar Biokimia Jilid 1. Jakarta: Erlangga.

12. Muchtadi D, Nurheni SP, dan Made A. 1992. Enzim dalam industri pangan. Bogor: Pusat Antar Universitas pangan dan Gizi IPB.

13. Murachi, T, Kamei A, dan Soedigdo P, 1982. Effect of Bongkrekic Acid.A product of Pseudomonas Cocovenenans. On Thiol Proteases, Toxicon 20: 1011-1017

14. Otto, HH dan T Schirmeister. 1997. Cysteine Proteases and Their Inhibitors. Chem. Rev. (97):133-171

15. Poedjiadi A. 2006. Dasar-dasar Biokimia. Jakarta: UI-Press.

16. Ranheim T, dan Halvorsen B. 2005. Coffee consumption and human health - beneficial or detrimental? - Mechanisms for effects of coffee consumption on different risk factors for cardiovascular disease and type 2 diabetes mellitus. Mol Nutr Food Research 49(3):274284.

17. Sabariyyah, P. 2005. Pemanfaatan Crude papain dalam produksi hidrolisat protein susu sapi. Departemen Biokimia Fakultas MIPAIPB.
18. Sadikin, M. 2002. Biokimia Enzim. Jakarta: Widya Medika.

19. Salisbury. FB, dan Ross CW. 1995. Fisiologi Tumbuhan, Jilid 2. penerjemah: Lukman DR, Sumaryono. Bandung:Penerbit ITB. Hal:145147.)

20. Shukor, Y. NA Baharom, FA Rahman, MP Abdullah, NA Shamaan, \& MA Syed. 2006. Development of a heavy metals enzymaticbased assay using papain. Anal. Chim.Acta (566):283-289

21. Soedigdo. P, dan Soedigdo S, 1977. Dimercaprol: A Suggested Antidote for Bongkrekic Acid Poisonings, 1\%' Federation of Asian and Oceanian Biochemists Congress. Nagoya, Abstract, pp: 112.

22. Suhartono, MT. 1991. Protease. Bogor: Pusat Antar Universitas Bioteknologi IPB.

23. Stedman, R.L. 1968. The Chemical Composition of Tobacco and Tobacco Smoke. Chemical Re-views. 68(2), hal: 153-207.

24. Susanna, D. 2003. Penentuan Kadar Nikotin. Makara Kesehatan. Universitas Indonesia. Jakarta.

25. Tutik, N. 2003. Pengaruh Konsentrasi Enzim Papain dan Suhu Fermentasi Terhadap Kualitas Keju Cottage. Program Studi Biologi FMIPA-ITS. Surabaya 